\section{左室短絡収縮率 $\left(\frac{\mathrm{Dd}-\mathrm{Ds}}{\mathrm{Dd}}\right)$}

UCG により心基部の左室短径収縮率を求めた。術前 平均 $0.35 \pm 0.08$ から術後 $0.24 \pm 0.06$ 之減少し, 左室 瘤例では左室健常心筋は過大な収縮運動を認めた。術前, I 群はII群より收縮率は大きく，術後は両群間の差は消 失した. 術後の収縮率が 0.2 以下を示した 4 例中 3 例 は術後の $\mathrm{EF}$ も 0.4 以下にとどまった。

心拍出量, LVEDP, ET/PEP, $\triangle \mathrm{ET}, \triangle \mathrm{PEP}$ について も術後両群ともに改善がみられた。

\section{考案および結語}

梗塞後の左室瘤の自然予後は不良で外科的左室瘤切除 術の著しい延命効果が広く認められている. 当科で行っ た左室瘤切除は 15 例で， 7 例は同時に A-C バイパス 術を行った. 手術死亡, 晚期死亡はともになく, 術後心 機能の改善が兄られた，2枝領域に心筋梗塞を有する例 では術後 EF の改善は不良であったが臨床症状に対して は著しい効果が得られた。

文 献 1) 藤原 巍ほか：外科 $42: 1554,1980$.

\title{
AIV-17 虚血性心疾患の合併症に対する外科治療
}

\begin{tabular}{lrrrrrr} 
& \multicolumn{1}{c}{ 日本医科大学 } & \multicolumn{2}{l}{ 胸部外科 } & & \\
山手 & 昇 & 二宮 淳一 & 池下 & 正敏 & 維田 & 隆夫 \\
落 & 雅美 & 佐々木建志 & 原田 & 厚 & 家所 & 良夫 \\
& & 庄司 & 佑 & & &
\end{tabular}

はじめに

虚血性心疾患の合併症に対する手術成績は未だ良好と はい壳ず，種々の問題がある。そこで，教室で経験した 虚血性心疾患に対する手術 114 例の弓ち, 心筋梗塞の合 併症 20 例飞ついての外科治療成績を検討した.

\section{対象・成績}

その手術症例は心室瘤 10 例，難治性不整脈 3 例，心 室中隔穿孔 5 例, 僧帽弁閉鎖不全 2 例である.

心室瘤切除術は心不全に対して行い，早期死 1 例, 晚 期死 3 例である. 早期死亡例は術前に LOS のため 8 日 間 IABPを使用した心腎不全を合併し心室瘤切除を行っ たが，術後 LOS は改善せず死亡した. 晚期死のうち 1 例は心臟死であり, また術後数年して 3 例㹟心発作が 生じた。したがって適応を党らべば，手術の危険上りも 長期予後が問題となり, 初回手術時に完全血行再建術を 行うことが重要である.

難治性心室性不整脈は 3 例とも広範な前側壁梗塞であ る(表 1 ). 症例 1 は梗塞後 26 病日に心室性頻拍が発 症した。内科治療に難治性となり, 冠動脈造影中に心室 性不整脈が頻発した。緊急手術のため術中電気生理学的
検査は行わず，心室瘤切除と心内膜切除を行った．しか 乙, 術後 LOS と高度の呼吸不全飞心室性頻拍・細動を 併発し死亡した，症例 2 は梗塞後 19 病日に心室性頻拍 が発症し， 28 病日に術中頻拍発作を誘発して心表面、 ッピングを行い，瘤切除と心内膜切除を行った．術後早 期に心室性不整脈が頻発したが, 抗不整脈剤でコントロ 一ルでき, 術後 94 病日より完全に抗不整脈剤を必要と しなくなった。しかし，術後 6 カ月に激症肝炎となり， その経過中に突然死した. 症例 3 は梗塞後 10 力月で心 室性頻拍を発症し, その後 2 力月間内科治療を行った。 術中 $38^{\circ} \mathrm{C}$ 常温下, non-working beating heart の状態 で，心室性頻拍発作を誘発じ，心内膜マッピングを行い， 最早期興奮部位を確めてから心内膜切除を行った。 術後 一過性に完全房室ブロックとなったが， A-V sequential pacingにより血行動態はよくコントロールされた. 術後 心室性不整脈は全く現われず, 現在術後 4 力月で健在で ある。

心室中隔穿孔の手術は梗塞発症後 14 日以内の急性期 3 例, 慢性期 2 例である (表 2 ). 手術時期と心室中隔 穿孔部の閉鎖方法についてみると, 症例 1 は中隔穿孔部 位の左室側にテフロンフェルトパッチをあて閉鎖した。 症例 2 は下壁梗塞であり， Daggett ${ }^{1)}$ らの方法に準じて， 
$13: 512$

日本心臓血管外科学会雑誌 $\quad 13$ 巻 6 号 (1984)

表 1 梗塞後の $\mathrm{VT} \cdot \mathrm{VF}$ 症例

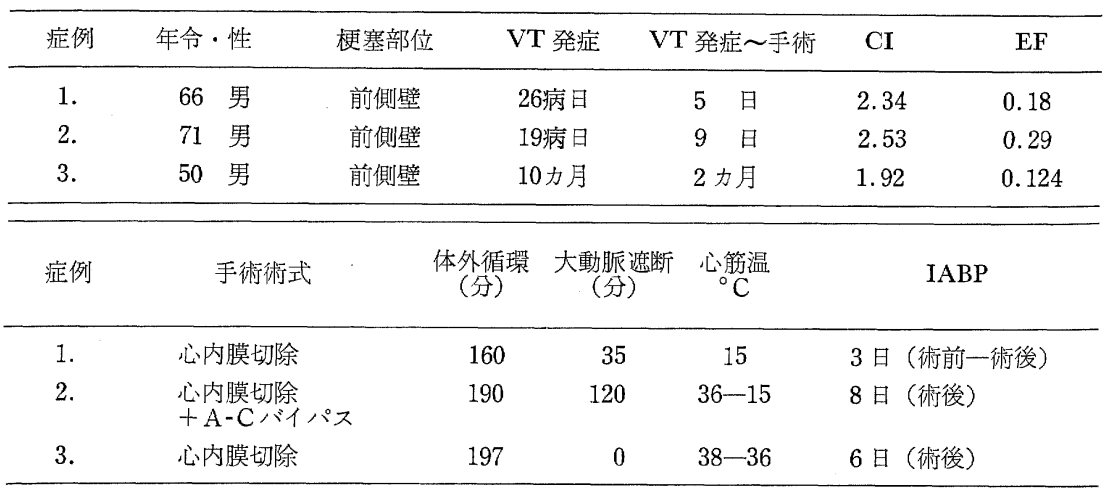

表 2 心室中隔穿孔の手術症例

\begin{tabular}{|c|c|c|c|c|c|c|c|}
\hline \multirow{2}{*}{ 症例 } & \multirow{2}{*}{ 年令・性 } & \multirow{2}{*}{ 梗塞部位 } & \multirow{2}{*}{ 梗塞～穿孔 } & \multirow{2}{*}{$\begin{array}{l}\text { 肺/体血 } \\
\text { 流比 }\end{array}$} & (IABP 時間) & \multirow{2}{*}{ 穿孔〜手術 } & \multirow{2}{*}{ 予 後 } \\
\hline & & & & & 術前 術後 & & \\
\hline 1. & 67 女 & 前 側 壁 & 6 日 & 2.80 & $73+24$ & 日 & 生 \\
\hline 2. & 72 女 & 下 壁 & 4 日 & 2.25 & $134+96$ & 日 & 生 \\
\hline 3. & 78 男 & 前 側 壁 & 11日 & 1.33 & 85 & 3 日 & 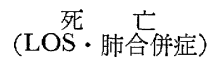 \\
\hline 4. & 55 女 & 前壁中隔 & 3 日 & 1.56 & 50 & 4 力月 & 生 \\
\hline 5. & 67 男 & 前 側 壁 & 22 日 & 1.49 & 50 & 5 力月 & 亡 $(\mathrm{LOS})$ \\
\hline
\end{tabular}

表 3 僧帽弁閉鎖不全の手術症例

\begin{tabular}{ccccccccc}
\hline 症例 & 年令・性 & 梗塞部位 & Forrester & Killip & IABP & 梗塞 手術 & 合 & 侀 症 \\
\hline 1. & 65 & 女 & 下 壁 & IV & IV & 4 日 & 40 日 & 腎不全・肝不全, 肺合併症 \\
2. & 66 & 男 & 前側壁 & IV & IV & 14 日 & 14 日 & 腎不全, 肺合併症 \\
\hline
\end{tabular}

心室中隔を右室壁に固定し穿孔部を閉鎖したのち，後壁 久損部位をパッチで閉鎖した。他の 3 症例は心室中隔を 右室壁飞固定し，穿孔部を閉鎖した。急性期に手術した 症例 3 は，術後 5 日目 IABPを抜去した翌日より収縮期 雑音が発生し, 肺合併症と心室中隔再穿孔で死亡した. 慢性期に手術した 症例 5 は術中冠動脈の spasmus を生 じ，人工心肺からの離脱に困難をきたし，術後 LOS で 死亡した.

僧帽弁閉鎖不全に対する手術は 2 例で，乳頭筋機能不 全が原因であった（表 3)．2 例とも収縮期雑音の発症 とともに心原性ショックとなり, 内科治療にて循環動態 は改善せず，Björk-Shiley 弁にて升置換術を行った。 2 例ともすで腎不全・肺合併症などの多臓器障害を括こ しており，術後早期死亡した。
心筋梗塞の合併症に対する手術 20 例のうち, 早期死 が 6 例あり, 問題点の多い所である。室瘤切除術によ る死亡例は術前より LOS, 腎不全をともない重症であり， 救命のためにはさらに手技上の工夫が必要である.

難治性心室性不整脈 3 例のうち, 比較的急性飞経過し た2 例では術後心室性不整脈が現われた。これらは心内 膜マッピングを行わなかった．心内膜マッピングを行っ た慢性経過症例は術後全く心室不整脈がみられなかった。 それゆ方, 心内膜マッピングは心室性頻拍の起始部を完 全に切除するために重要な検查法であると考光られる.

心室中隔穿孔の急性期症例では梗塞部位が脆弱である. 心室中隔再穿孔の対策として，1）脆弱な心室中隔穿孔 
部位を十分切除し，心室中隔の左室側にテフロンパッチ をあて穿孔部を閉鎖する，2）IABP による後負荷の減 少がある。一方, 心機能の状態からみた手術時期は, シ ョック症例では IABP 開始後 24 時間以内に手術が,必要 である．重症心不全例では IABP の効果は一過性であり， 数日後心不全は堌悪する. 循環動態の改善がみられない
ものは梗塞発症後 2 週間以内に手術すべきである.

僧帽弁閉鎖不全では心室中隔穿孔例と同様にショック 症例では緊急手術を行う．重症心不全症例では多藏器の 障害がおこる前に早期手術が望をれる.

文 献 1) Daggett, W. M.: World. J. Surg. $2: 753,1978$.

\section{AIV-18 僧帽弁閉鎖不全を合併した心室瘤に対する外科治療}

\begin{tabular}{|c|c|c|c|c|c|c|c|}
\hline 湯浅 & 浩 & 大井 & 勉 & 森本 & 保 & 坂井 & $\begin{array}{c}\text { 心缄 } \\
\text { 隆 }\end{array}$ \\
\hline 庄村 & 赤裸 & 山崎 & 順彦 & 千種 & 弘章 & 草川 & 実 \\
\hline 増田 & 浩一* & 水谷 & $\begin{array}{l}\text { 哲夫* } \\
\text { 木下 }\end{array}$ & $\begin{array}{l}\text { 新実 } \\
\text { 肇彦** }\end{array}$ & 藤昭* & 藤井 & 英樹** \\
\hline
\end{tabular}

昭和 48 年以降, 192 例の虚血性心疾患に手術を行い, このらち心室瘤に 対する手術は 30 例である。，心室瘤 30 例中手術近接死 1 例， $3 \%$ と汪活満足すべき成績で ある. しかし, 生存例 29 例の術後臨床症状は, 僧帽弁 閉鎖不全（以下 MR）を合併しない 21 例中 18 例, $85.7 \%$ は NYHA I 度に改善されたのに対し, MR(十) 群 8 例では, 術後 MR の消失した 5 例, $62.5 \%$ は NY HA I 度に改善したが，術後 1 ないし 3 度の MR 残存 を認める 3 例， $37.5 \%$ では NYHA II 度に止まってい る.
行動態を検討し報告する.

対象は, 男 7 例, 女 1 例の計 8 例で, 年令は最低 31 才, 最高 64 才, 前壁, 前側壁あるいは前壁中隔に梗塞 を認めるもの 7 例, 後壁梗塞を認めるもの 2 例である. $75 \%$ 以上の狭窄を認める冠動脈病変は，7 例で前下行 枝に，3例で回旋枝に，3 例に右冠動脈に認めたが，症 例 8 は冠動脈狭窄を認めない冠動脈孌縮による心䇗梗塞 であった．MR の程度と術前臨床症状との関係は，MR の高度な症例では NYHA IIIないしIV度であるが，MR が軽度の症例でも NYHA IV度のものもあり, MR の程 度と臨床症状は必ずしも一致しなかった。これは, 本症

表 1 僧帽弁閉鎖不全を合併した心室瘤症例

\begin{tabular}{|c|c|c|c|c|c|c|c|c|c|}
\hline 症 & 例・年 & 令・性 & & 梗塞部位 & 左軸偏位 & 不整脈 & 冠状動哌病変 & NYHA & $\begin{array}{l}\text { MR } \\
\text { 程 度 }\end{array}$ \\
\hline 1. & & 52 & 男 & 前 側 壁 & $(+)$ & $(-)$ & LAD $90 \%$ & III & 2 \\
\hline 2. & & 31 & 男 & $\begin{cases}\text { 前 } & \text { 譬 } \\
\text { 壁 }\end{cases}$ & $(+)$ & $(+)$ & $\begin{cases}\text { LAD } & 100 \% \\
\mathrm{CX} & 100 \%\end{cases}$ & IV & 3 \\
\hline 3. & & 48 & 男 & 前 壁 & $(-)$ & $(+)$ & $\begin{cases}\text { LAD } & 90 \% \\
\mathrm{CX} & 90 \%\end{cases}$ & II & 1 \\
\hline 4. & & 64 & 男 & 前壁 & $(-)$ & $(-)$ & $\left\{\begin{array}{l}\text { RCA } 100 \% \\
\text { LAD } 100 \% \\
\text { CX } 50 \%\end{array}\right.$ & IV & 2 \\
\hline 5. & & 58 & 男 & 前壁中隔 & $(+)$ & $(-)$ & $\begin{cases}\text { RCA } & 75 \% \\
\text { LAD } & 90 \% \\
\text { CX } & 75 \%\end{cases}$ & III & 3 \\
\hline 6. & & 57 & 男 & 前壁中隔 & $(+)$ & (H) & $\begin{cases}\text { RCA } & 75 \% \\
\text { LAD } & 90 \%\end{cases}$ & III & 2 \\
\hline 7. & & 63 & 女 & 前壁中隔 & $(+)$ & $(-)$ & LAD $90 \%$ & IV & 1 \\
\hline 8. & & 64 & 男 & 後 壁 & $(-)$ & $(-)$ & 冠動脈攣縮 & III & 4 \\
\hline
\end{tabular}

